\title{
Identification of antileucoprotease in remodelled human adult nasal surface epithelium
}

\author{
V. Marchand ${ }^{*}$, J-M. Tournier*, M. Chevillard*, M. Polette*, \\ A. Beorchia*, J-M. Klossek ${ }^{\star *}$, E. Puchelle
}

Identification of antileucoprotease in remodelled human adult nasal surface epithelium. V. Marchand, J-M. Tournier, M. Chevillard, M. Polette, A. Beorchia, J-M. Klossek, E. Puchelle. CERS Journals Ltd 1995.

ABSTRACT: Antileucoprotease (ALP) is generally considered as a specific marker for glandular serous cells, and plays a major role in the defence of the respiratory tract against proteolytic damage. Nevertheless, several studies have identified ALP in bronchial and bronchiolar surface epithelial cells, and also an increased number of ALP-containing cells in bronchiolar tissue during the development of pulmonary diseases. In order to define more clearly whether the surface epithelium might be involved in the defence of the respiratory mucosa, we have investigated the expression of ALP by cells of the nasal surface epithelium.

Indirect immunocytochemistry and in situ hybridization for ALP were performed on human nasal polyp sections. The height of the surface epithelium, its morphology, and the degree of local inflammation were assessed in parallel.

Surface epithelium morphology was highly heterogeneous. ALP-containing cells were identified, but only in remodelled areas of the surface epithelium (foldings, basal cell and/or mucous cell hyperplasia), with no association to the degree of inflammation.

These results demonstrate that the surface epithelial cells of the human adult nasal mucosa can express ALP in remodelled surface epithelium, and may be actively involved in the biochemical defence of the airways. Eur Respir J., 1995, 8, 15-21.
*INSERM U314, Université de Reims, France. **Hôpital Jean Bernard, Poitiers, France.

Correspondence: V. Marchand

INSERM U314

CHR Maison Blanche

45 Rue Cognacq Jay

51092 Reims Cedex

France

Keywords: Antileucoprotease

basal cell hyperplasia

mucous cell hyperplasia

nasal surface epithelium

Received: April 111994

Accepted after revision October 261994

This work has been supported by a grant (No. 915739) from The Région ChampagneArdenne, France.
A low molecular weight proteinase inhibitor, found in bronchial secretions and capable of inhibiting leucocyte proteinases $[1,2]$, is synthesized locally by airway epithelial cells [3]. This proteinase inhibitor, generally referred to as antileucoprotease (ALP) [4], plays a major physiological role in the inactivation of neutrophil elastase bound to elastin $[5,6]$. In the respiratory tract, ALP has been localized in the serous cells of the submucosal nasal $[3,7]$, tracheal and bronchial glands $[3,8]$, and in some nonciliated cells of the bronchiolar epithelium, where glands are absent [9]. Recent studies have been carried out to estimate the number of ALP-containing cells in relation to pathological situations. WILLEMS et al. [10] showed that, in small airway diseases, parenchymal destruction is associated with an increased number of ALP-containing cells in respiratory bronchioles, suggesting a role for ALP in the general defence against inflammatory and destructive processes in the distal airways. The increase in the number of ALP-containing cells was found in areas of mucous cell or squamous cell metaplasia [10]. KIDA et al. [11] also reported an increased number of ALP-containing cells in human bronchial and bronchiolar structures, together with mucous cell hyperplasia, associated with the existence of acute inflammatory changes in the alveolar region.

These data led us to address the question of whether normal and remodelled surface epithelium of the upper airways could express ALP. Using the nasal polyp as a model of inflamed and remodelled respiratory tissue, we investigated the localization of ALP messenger ribonucleic acid (mRNA) transcripts and ALP protein in human nasal tissue, and analysed their distribution in relation to the morphological aspect and the degree of inflammation of the airway epithelium.

\section{Materials and methods}

\section{Tissue preparation}

Human nasal polyps were obtained from six nonallergic patients undergoing nasal polypectomy for nasal obstruction. These patients did not show any sign of blood eosinophilia, and they presented normal range of total serum immunoglobulin $\mathrm{E}$ ( $\mathrm{IgE})$, negative radioallergosorbant tests, and negative skin-prick tests. Most 
of the patients (five out of six) had been using antiinflammatory (corticosteroids) medication just prior to polypectomy. Immediately after excision, tissue samples were immersed in RPMI 1640 medium (Seromed, Biochrom $\mathrm{KG}$, Berlin, Germany), containing $100 \mathrm{U} \cdot \mathrm{ml}^{-1}$ penicillin, $100 \mu \mathrm{g} \cdot \mathrm{ml}^{-1}$ streptomycin, and $20 \mathrm{mM}$ hydroxyethylpiperazine ethanesulphonic acid (Hepes)(GIBCO, Grand Island, NY, USA). The polyp samples were transferred to our laboratory within $24 \mathrm{~h}$ in this conservation medium.

A sample of each nasal polyp was fixed for $1 \mathrm{~h}$ at $4{ }^{\circ} \mathrm{C}$ in $4 \%$ paraformaldehyde, rinsed three times for $15 \mathrm{~min}$ in $0.1 \mathrm{M}$ phosphate buffer $\mathrm{pH} 7.2$, then dehydrated through graded concentrations of ethanol and embedded in paraffin. Sections $3 \mu \mathrm{m}$ thick were then prepared on a microtome and transferred onto gelatin-coated glass slides.

\section{Morphological observations}

Paraffin sections from six nasal polyps were analysed along the total observable surface epithelium, using a light microscope equipped with a reticular objective. Four types of surface epithelium (normal or remodelled) were distinguished according to their morphology. The relative occurrence of each morphological type, expressed as a percentage of the whole, was calculated for each sample. The length of the surface epithelium observed varied from 1,160 to $7,900 \mu \mathrm{m}$, with approximately 100-800 cells. The height of the surface epithelium in each morphological type of epithelium was calculated in each sample. The mean number of inflammatory cells in the surface epithelium and in the underlying connective tissue was calculated in ALP-positive and ALP-negative areas of five polyp samples. This number of inflammatory cells was assessed from haematoxylinphloxine-safranin (HPS) stained serial sections.

\section{Immunohistochemistry}

Paraffin sections were dewaxed in xylene, and incubated for 5 min with $3 \%$ hydrogen peroxide $\left(\mathrm{H}_{2} \mathrm{O}_{2}\right)$ in water, to inhibit the endogenous peroxidase activity. After two washes in $0.1 \mathrm{M}$ phosphate buffer (PB) $\mathrm{pH} 7.4$ for 5 min, nonspecific fixation sites were saturated by treating all sections for 10 min with $10 \%$ normal goat serum in PB. This was followed by a $1 \mathrm{~h}$ incubation in $3 \mu \mathrm{g} \cdot \mathrm{ml}^{-1}$ rabbit immunoglobulin $\mathrm{G}$ ( $\mathrm{IgG}$ ) anti-human antileucoprotease [12] in $0.1 \mathrm{M}$ PB containing 5\% normal goat serum (NGS-PB). The sections were then washed twice for $5 \mathrm{~min}$ in $\mathrm{PB}$ and for $10 \mathrm{~min}$ in NGS-PB, followed by a $1 \mathrm{~h}$ incubation with biotinylated donkey antirabbit IgG (Amersham) (1:250). The sections were washed twice for $5 \mathrm{~min}$ in PB and for $10 \mathrm{~min}$ in NGS$\mathrm{PB}$, and incubated with streptavidin-biotin-peroxidase complex (Amersham) (1:250). The sections were washed four times with PB for $5 \mathrm{~min}$ and incubated in $0.1 \%$ 3.3'diaminobenzidine tetrahydrochloride (Sigma Chemical), $0.1 \% \mathrm{H}_{2} \mathrm{O}_{2}$, and $0.1 \%$ imidazol (Sigma) in distilled water. The sections were then incubated for $5 \mathrm{~min}$ in the dark with the chromogenic solution. The enzymatic activity of peroxidase was stopped by immersing the slices in distilled water. All of the steps were carried out at room temperature. Cells were then counterstained with haematoxylin, and glass coverslips were mounted on the sections with Aquamount. Observations were made using an Axiophot microscope (Zeiss).

Negative controls were performed by either omitting the ALP antibody, or replacing it with normal rabbit serum IgG at the same concentration $\left(3 \mu \mathrm{g} \cdot \mathrm{ml}^{-1}\right)$.

\section{Hybridization}

Nature of the probe. The plasmid pRH 1807, which is a pUC18 derivative that contains the PstI complementary deoxyribonucleic acid (cDNA) insert of pRH 34 was kindly provided by R. HEINZEL [13]; this insert contains the whole coding region for ALP. Northern blot analysis of total ribonucleic acid (RNA) extracted from human respiratory cells revealed a single band of $0.7 \mathrm{~Kb}$ [14], which agrees with the results of HeINZEL et al. [13] with RNA from human cervix uteri.

In situ hybridization. Paraffin sections of nasal polyps were dewaxed in xylene, transferred in a $2 \mathrm{X}$ standard saline citrate (SSC: $0.3 \mathrm{M} \mathrm{NaCl}, 0.03 \mathrm{M}$ Tris-Na citrate) solution, and incubated for $10 \mathrm{~min}$ in fresh $0.25 \%$ acetic anhydride in $0.1 \mathrm{M}$ triethanolamine, $\mathrm{pH}$ 8.0. After washings in $2 \mathrm{X} \mathrm{SSC}$, the sections were immersed at $55^{\circ} \mathrm{C}$ in $50 \%$ formamide in 2 X SSC solution for $10 \mathrm{~min}$. The radiolabelled cDNA probe was prepared by the random priming technique (Multiprime DNA, labelling system; Amersham, Little Chalfort, UK) using ${ }^{35} \mathrm{~S}$-labelled $\mathrm{dCTP}\left(600 \mathrm{Ci} \cdot \mathrm{mM}^{-1}, 10 \mathrm{mCi} \cdot \mathrm{ml}^{-1}\right.$, Amersham, UK). Hybridization of this probe was performed in $10 \mathrm{mM}$ Tris $\mathrm{pH}$ 7.0 containing $50 \%$ formamide, $0.6 \mathrm{M} \mathrm{NaCl}, 1 \mathrm{mM}$ ethylenediamine tetraacetic acid (EDTA), $1 \mathrm{X}$ Denhardt's solution, $250 \mu \mathrm{g} \cdot \mathrm{ml}^{-1}$ heat-denatured salmon sperm, 500 $\mu \mathrm{g} \cdot \mathrm{ml}^{-1}$ yeast transfer ribonucleic acid (tRNA), $10 \%$ dextran sulphate and $10 \mathrm{mM}$ dithiothreitol. The denatured labelled probe was applied to tissue sections at a concentration of $1 \mathrm{ng} \cdot 10 \mu \mathrm{l}^{-1}$ of the hybridization solution. Denaturation of the probe was carried out by heating at $80^{\circ} \mathrm{C}$ for $10 \mathrm{~min}$. Each tissue section was covered with $10 \mu \mathrm{l}$ of the hybridization solution and a siliconized coverslip, and then incubated for $42 \mathrm{~h}$ at $42^{\circ} \mathrm{C}$ in a moist chamber. After hybridization, tissue sections were washed $3 \times 5 \mathrm{~min}$ at room temperature in $2 \mathrm{X} \mathrm{SSC}, 3 \times 5 \mathrm{~min}$ in 1 X SSC, and for $5 \mathrm{~min}$ in $0.5 \mathrm{X} \mathrm{SSC}$. Sections were then dehydrated in 50, 70, and $100 \%$ ethanol containing $600 \mathrm{mM}$ ammonium acetate, and air dried prior to autoradiography. Sections were dipped into K5 Ilford emulsion, dried and exposed for 28 days at $-20^{\circ} \mathrm{C}$. They were developed in D19 Kodak, HPS stained and coverslipped. Observations were made by using an Axiophot microscope (Zeiss).

Negative controls for in situ hybridization were performed by treating tissue sections with ribonuclease (RNase) $\left(100 \mu \mathrm{g} \cdot \mathrm{ml}^{-1}\right.$ in $\left.2 \mathrm{X} \mathrm{SSC}\right)$ before prehybridization treatment. 


\section{Quantitation of ALP transcripts labelling}

The density of labelling obtained by in situ hybridization of the ALP cDNA probe over the surface epithelium was quantitatively evaluated. Eleven areas of the surface epithelium were observed. For each area studied, black and white photographs were taken using successive Nomarski differential interference illumination and epifluorescence in dark fields. The quantitative determination of dense markers on the sections was performed on an image analyser (Biocom 500; Les Ulis; France). The program, based on mathematical morphology, automatically detects and counts dense markers [15]. The segmentation of the contours was performed manually with the help of a graphic mouse, in both the surface epithelium and in an area of the connective tissue. The density of markers was expressed as number of markers by $\mu \mathrm{m}^{2}$ area.

Relationship between the ALP labelling and the degree of inflammation

This study was performed on 26 microscope fields from five nasal polyp samples previously characterized for ALP immunolocalization on serial sections. Inflammatory cells (lymphocytes and polymorphonuclear neutrophils) were identified from morphological characteristics after HPS staining, in areas where the surface epithelium was known to be ALP-positive or ALP-negative. The results were expressed as number of inflammatory cells $\cdot \mathrm{mm}^{-2}$, in the surface epithelium or in the underlying connective tissue.

\section{Statistical analysis}

Nonparametric tests were used. Comparisons of the number of inflammatory cells and of the height of the surface epithelium in normal and remodelled areas were made using a Mann-Whitney test. Comparison of the density of markers after in situ hybridization between the surface epithelium and the underlying connective tissue was made using a Wilcoxon test. All the values were expressed as medians with range in brackets and considered to be significantly different at a value of $\mathrm{p}<0.05$.

\section{Results}

\section{Morphological aspect of the surface epithelium}

In the surface epithelium observed, four morphological types could be distinguished, corresponding to either: 1) normal surface epithelium without any remodelling; 2) invagination or folding of the surface epithelium; 3 ) basal cell hyperplasia; or 4) mucous cell hyperplasia (fig. 1). Normal surface epithelium was pseudostratified and composed of ciliated cells, mucous cells and basal cells (fig. 1a) (ratio of 1 mucous cell: 5 ciliated cells). In some areas, we occasionally observed foldings (fig. 1b). Basal cell hyperplasia (fig. 1c) was characterized by the presence of at least three layers of basal cells, whilst mucous cell hyperplasia (fig. 1d) was characterized by an increased number of mucous cells in comparison with the normal structure (ratio of $>1$ mucous cell: 3 ciliated cells). Some areas of remodelled epithelium a)

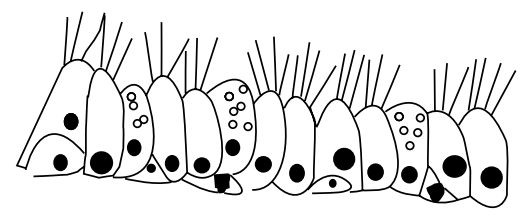

c)

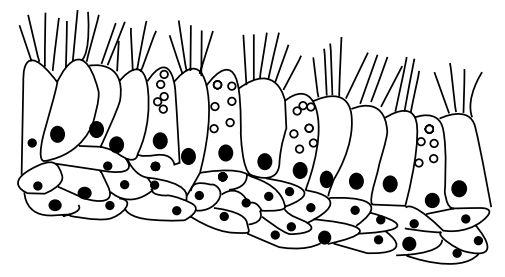

b)
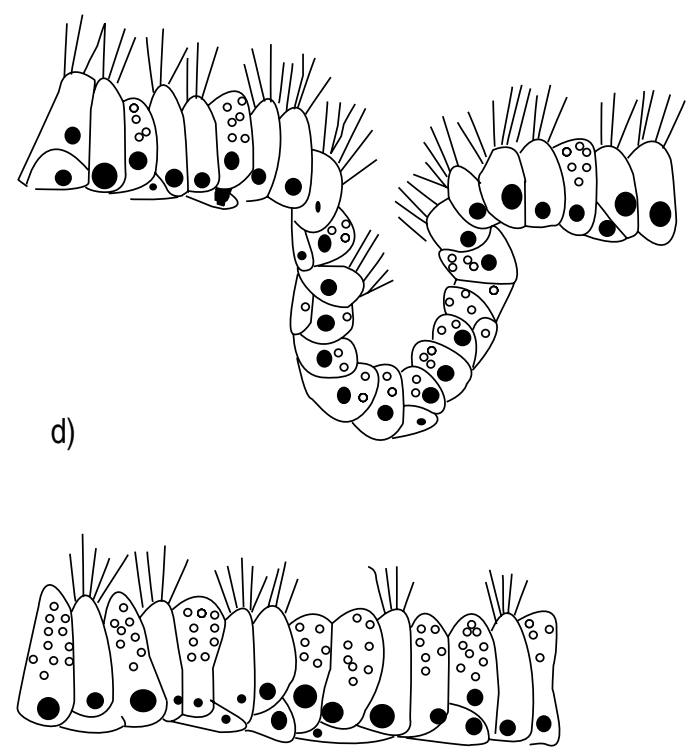

Fig. 1. - Classification of the different morphological aspects of the surface respiratory epithelium. a) Normal pseudostratified epithelium, composed of ciliated cells, mucous cells and basal cells. b) Folding of a pseudostratified surface epithelium. c) Area of basal cell hyperplasia, characterized by at least three layers of basal cells. d) Area of mucous cell hyperplasia, characterized by an increased number of mucous cells, in comparison with the pseudostratified surface epithelium. 
had both basal and mucous hyperplasia, but were classified in the subtype of basal cell hyperplasia.

\section{Relative percentages of each morphological aspect of the surface epithelium}

The relative proportion of each of the four morphological types of surface epithelium defined in figure 1 was calculated in each sample. There were huge differences from one polyp to another. Only three of six polyp samples presented a normal aspect along their entire surface epithelium, this normal aspect representing $10-90 \%$ of the whole. Most of the surface epithelium observed exhibited remodelling, and the most frequently identified pattern was basal cell hyperplasia.

\section{Height of the surface epithelium}

No significant difference was observed between the height of the surface epithelium, whether it was normal (median $60 \mu \mathrm{m}$; range $40-60 \mu \mathrm{m} ; \mathrm{n}=3$ ) or remodelled (median $40 \mu \mathrm{m}$; range $20-80 \mu \mathrm{m} ; \mathrm{n}=15$ ).

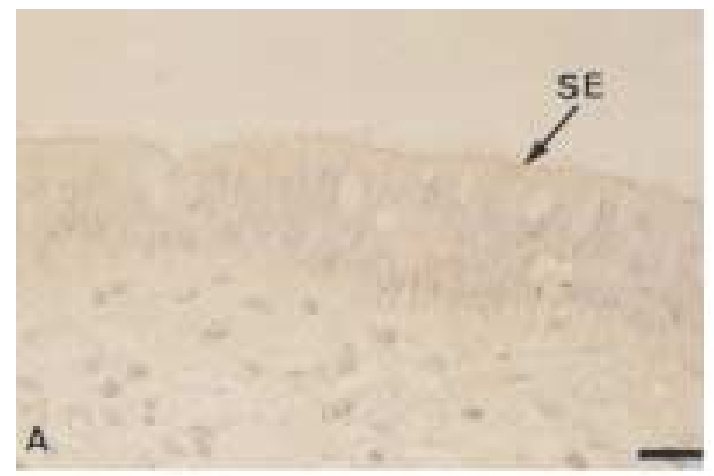

\section{Immunolocalization of ALP}

In the nasal polyp tissue, ALP was generally localized in the glandular epithelium; whereas, the normal surface epithelium contained no ALP (fig. 2a). In the glandular epithelium ALP was exclusively located in the serous cells; whereas, the mucous cells contained no ALP (fig. 2b). Nevertheless, ALP was identified in surface epithelium cells of remodelled areas in some cuboidal cells of folds in the surface epithelium (fig. 2c); in secretory cells in areas of mucous cell hyperplasia (fig. 2d); as well as in some intermediate cells in areas of basal cell hyperplasia (fig. 2e). Negative controls, consisting of incubation without primary antibody or with nonimmune serum replacing the primary antibody, always gave negative results; no staining ever appeared in these sections (data not shown).

\section{In situ hybridization}

The presence of ALP transcripts was demonstrated in remodelled areas of the surface epithelium (fig. 3).
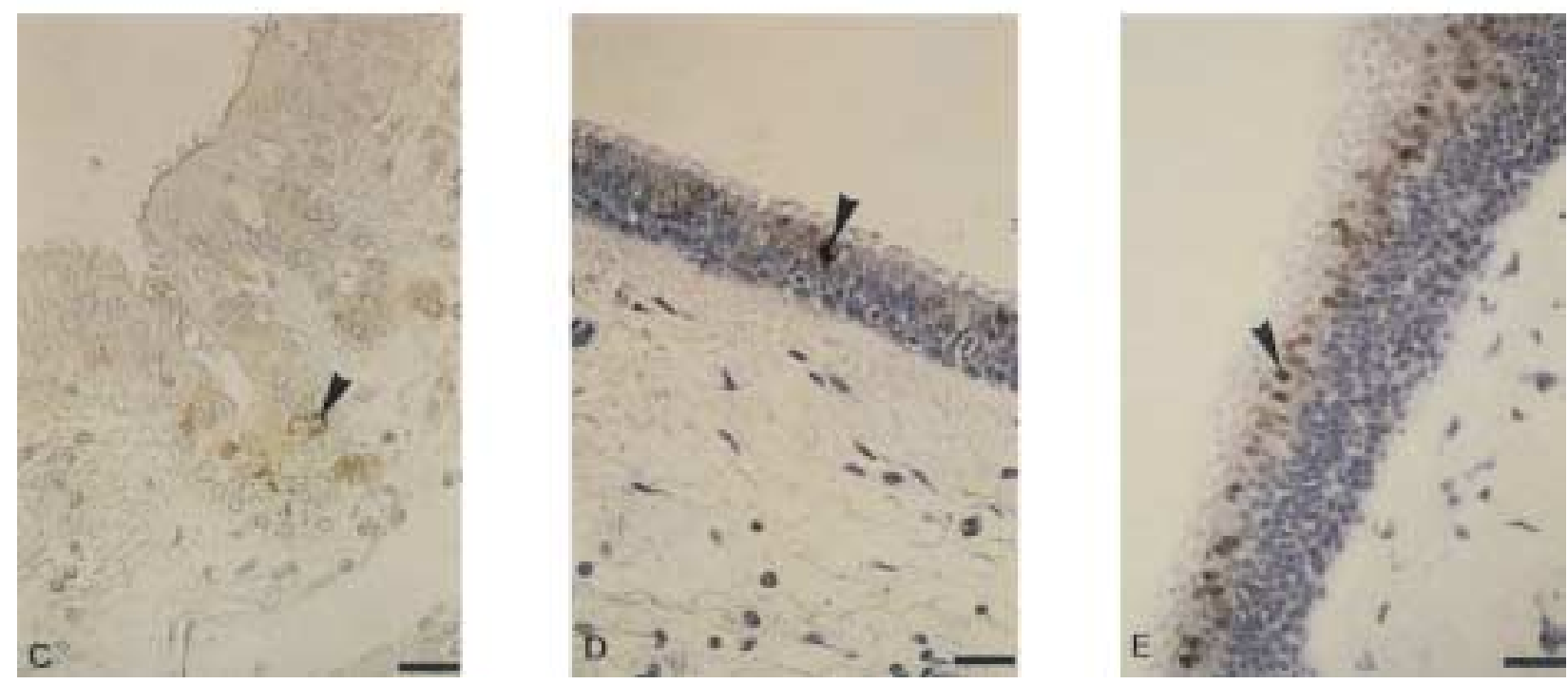

Fig. 2. - Immunohistochemical localization of antileucoprotease (ALP) in human nasal polyps. Indirect immunoperoxidase and haematoxylin counterstaining on paraffin sections. The presence of ALP is shown by large arrowheads. A) The surface epithelium (SE) generally contains no ALP. B) In a glandular structure, ALP is localized in the serous cells (S), not in the mucous cells (M). C) Presence of ALP in some surface epithelial cells of a structure appearing as a folding of the surface epithelium. D) Presence of ALP in some secretory cells of a mucous cell hyperplasia area. E) Presence of ALP in some intermediate cells of a basal cell hyperplasia area. (Internal scale bar=20 $\mu \mathrm{m}$ ). 

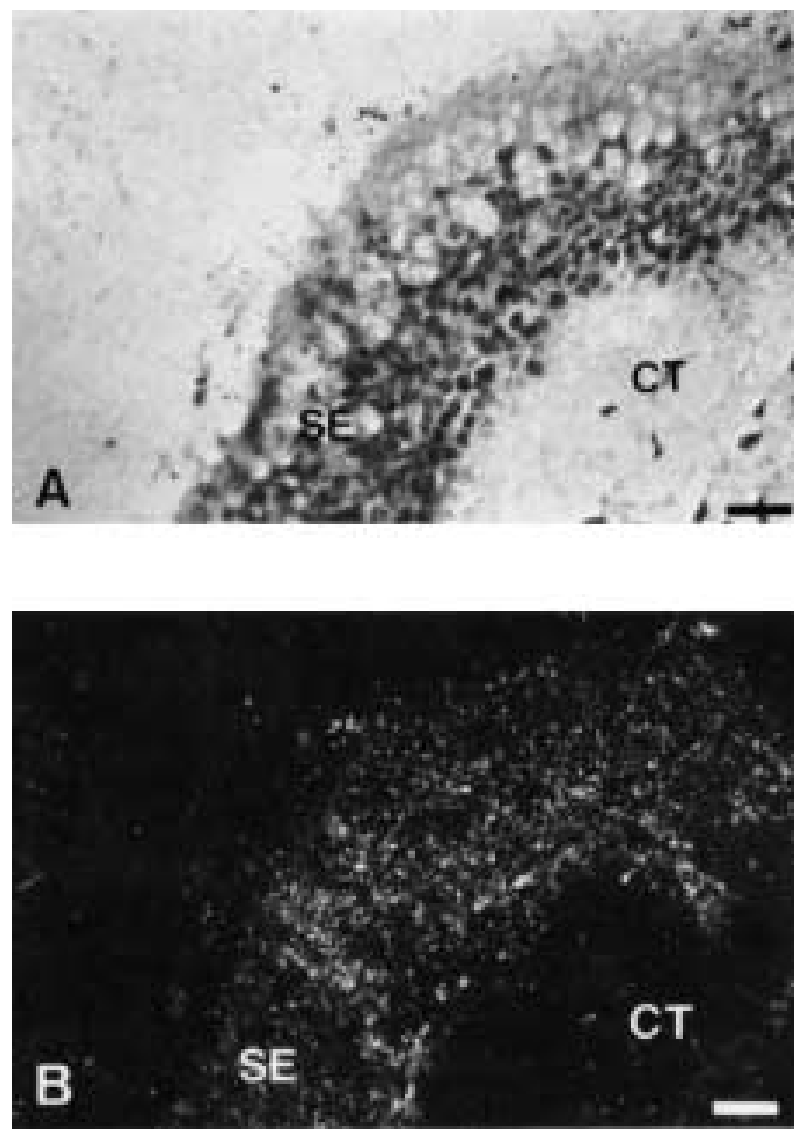

Fig. 3. - Detection of antileucoprotease (ALP) transcripts in the surface epithelium of human nasal polyps. Paraffin-embedded nasal polyp sections stained with haematoxylin-phloxine-safranin (HPS), after in situ hybridization of a ${ }^{35} \mathrm{~S}$-labelled complementary deoxyribonucleic acid (cDNA) probe. A) Observations with a Zeiss microscope using Nomarski differential interference illumination. SE: surface epithelium; CT: connective tissue. B) The same area observed in dark field epifluorescence: visualization of the markers. (Internal scale bar=20 $\mu \mathrm{m})$.

In these areas, the density of markers in the surface epithe-

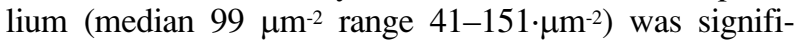
cantly greater than that in the underlying connective tissue (median $21 \mu \mathrm{m}^{-2}$ range $\left.0-81 \mu \mathrm{m}^{-2}\right)(\mathrm{p}=0.002)$. After incubation with RNase, no hybridization of the probe was observed on the tissue sections (data not shown).

Relationship between the ALP labelling and the morphological aspect of the surface epithelium

No ALP-containing cell appeared in normal areas of pseudostratified surface epithelium, in contrast with the three remodelled structures of the surface epithelium, in which ALP-containing cells were observed. None of these three remodelled aspects of the surface epithelium was systematically associated with the presence of ALPcontaining cells: some areas exhibited ALP-containing cells whilst other areas did not.
Relationship between the ALP labelling and the degree of inflammation

No significant difference was observed in the number of intraepithelial inflammatory cells $\mathrm{mm}^{-2}$ between ALPlabelled areas (median $64 \mathrm{~mm}^{-2}$; range $21-115 \mathrm{~mm}^{-2}$ ) and ALP-unlabelled areas (median $46 \mathrm{~mm}^{-2}$; range 25-79 $\mathrm{mm}^{-2}$ ). The same result was observed when comparing the number of inflammatory cells present in the connective tissue underlying ALP-labelled areas (median 206 $\mathrm{mm}^{-2}$; range 129-941 $\mathrm{mm}^{-2}$; ) and ALP-unlabelled areas (median $264 \mathrm{~mm}^{-2}$; range135-503 $\mathrm{mm}^{-2}$ ).

\section{Discussion}

This study clearly shows that human adult nasal surface epithelial cells can express antileucoprotease (ALP), where the epithelium has become remodelled.

Various patterns of surface epithelium were observed in the polyp samples, appearing as normal (pseudostratified) or remodelled (folding of the surface epithelium, mucous cell hyperplasia and/or basal cell hyperplasia) structures. Areas of basal cell hyperplasia and/or mucous cell hyperplasia have already been described in vivo and may precede squamous cell metaplasia [16], a more radical alteration of the respiratory mucosa $[17,18]$, which was not seen in our study. Basal cell and mucous cell hyperplasia are often considered as reversible lesions that occur as adaptive changes of the epithelium, and are thought to play a physiological role in the defence mechanisms of the repiratory mucosa [16]. Foldings of the surface epithelium might be considered as a part of a collecting duct of the glandular epithelium [19, 20]. But it is also possible that some of these structures could be associated with a remodelling process of the surface epithelium, and could represent dynamic invaginations of the surface epithelium in the connective tissue to form new glandular structures [21], as observed during embryogenesis [20, 22].

When investigating the localization of ALP in human nasal polyp sections, we observed a different distribution of this molecule according to the type of mucosa. Whenever the morphological aspect was normal, no ALPcontaining cells appeared in the surface epithelium. But ALP-containing cells could be identified in areas with a remodelled morphological aspect. During embryogenesis, some serous cells [23], and ALP-containing cells [24], have been identified in human foetal surface epithelium. Our results show the presence of ALP in some adult surface epithelial cells, suggesting that foetal characteristics might appear in adult respiratory cells. This hypothesis is supported by the findings of JEFFERY et al. [20], who have recently described similar characteristics of bronchial secretions during development and also during the pathology of bronchitis.

In order to ascertain whether human surface epithelial cells are able to synthesize ALP, we performed in situ hybridization of a cDNA probe on human nasal polyp tissue. ALP mRNA transcripts were identified in the surface epithelium. This observation, associated with 
the immunohistochemical localization of the protein, allowed us to conclude that ALP can be expressed not only by glandular serous cells, but also by some surface epithelial cells in specific conditions.

WILLEMS et al. [19] have already reported the presence of ALP in some rare isolated human epithelial cells, and also in some cells of structures identified as being collecting ducts. In the nasal turbinate mucosa, LeE et al. [7] have recently shown that ALP was only identified in the serous submucosal glands, while no positive immunocytochemical staining was observed in the surface epithelium, including the goblet cells. Our findings are in complete agreement with the previously described localization of ALP in human nasal tissue, since we never observed ALP in normal pseudostratified surface epithelium. The originality of our study is to demonstrate the presence of ALP in areas of human nasal surface epithelial cells which have undergone remodelling.

The ability of human adult nasal surface epithelial cells to form gland-like structures in a collagen gel has been recently demonstrated in vitro [25]. In vivo, the presence of glandular cell markers in surface epithelial cells of remodelled epithelia have already been described. NIIMI et al. [26] demonstrated the appearance of the epithelial membrane antigen and the secretory component of immunoglobulin A ( $\operatorname{IgA}$ ) in human bronchial surface epithelial cells in cases of basal cell hyperplasia and later stages of lesions with stratification and squamous metaplasia of the surface epithelium. These authors suggested that the presence of these two glandular cell markers in remodelled surface epithelia might represent differentiation towards glandular epithelium. Recently, Rogers et al. [27] demonstrated, for the first time, the presence of serous cells in adult human bronchioles, on the basis of morphological criteria. This latter study has been carried out with lung tissues which were macroscopically normal, although derived from smoker and ex-smoker patients with well-localized tumours. It is possible that the identification of serous cells in the surface epithelium of human bronchioles could also be related to the injury of the respiratory mucosa due to smoking, and might not be a normal characteristic of the human bronchiolar epithelium. The expression of an epidermal serine proteinase inhibitor, skin-derived antileucoproteinase (SKALP) or elafin, has been demonstrated to be associated with a remodelled phenotype of the skin. A differential expression of this molecule was observed in various epidermal tumours whilst no SKALP has been observed in normal human epidermis [28]. All of these observations support the hypothesis that human surface epithelia might be able to express glandular characteristics, in association with a remodelling process of the surface epithelium.

According to NORLANDER et al. [29], the polyp formation appears to be the result of a continuous inflammatory reaction. During inflammatory processes, neutrophil elastase is actively secreted, and this molecule is, to this day, the only molecule thought to be capable of modulating the expression of ALP [30]. The role of neutrophil elastase is to assist in the elimination of foreign molecules or micro-organisms, but it can also indiscriminately damage the respiratory tissue, and the major physiological role of ALP is the inactivation of neutrophil elastase [4]. AbBinante-Nissen et al. [30] demonstrated that neutrophil elastase itself is able to increase by 5-20 fold the levels of ALP mRNA transcripts in airway epithelial cells in culture. Inflammatory stimuli have been demonstrated to stimulate the ALP gene expression by a human bronchial squamous carcinoma cell line [31]. We therefore investigated the possibility that ALP labelling in the surface epithelium could be associated with a local increased degree of inflammation. The stimulation of the expression of ALP by surface epithelial cells does not appear to be associated with an increased number of inflammatory cells in the ALPpositive areas. Nevertheless, it is possible that higher concentrations of elastase might be present in these areas, and we now intend to study in vitro the effect of human neutrophil elastase on the expression of ALP by human nasal surface epithelial cells.

Our study, demonstrating the capacity of nasal surface epithelial cells to express ALP, highlights the involvement of the surface epithelium in the preliminary defence mechanisms of the respiratory epithelium. The expression of ALP in remodelled surface respiratory epithelium means that this protein should no longer be considered a specific glandular secretory marker. During epithelial remodelling, it could reinforce the antiprotease screen of the surface epithelium; thereby, protecting both the epithelium and underlying tissues.

Acknowledgements: The authors thank R. HeinzelWieland (Department of Molecular Biology, Grünenthal $\mathrm{GmbH}$, Aachen, Germany) for the gift of the ALP cDNA probe; J.M. Klossek (CHU Poitiers, France) for kindly providing the human polyp samples; D. Gaillard and S. Girod de Bentzmann for their contribution and their constructive comments in the preparation of the manuscript; C. Fuchey, N. Lalun and C. Lechki for their technical input.

\section{References}

1, Hochstrasser K, Reichert R, Schwarz S, Werle E. Isolierung und Charakterisierung eines Proteaseninhibitors aus menschlichem Bronkialsekret. Hoppe-Seyler's Z Physiol Chem 1972; 353: 221.

2. Ohlsson K, Tegner H. Inhibition of elastase from granulocytes by the low molecular weight bronchial protease inhibitor. Scand J Clin Lab Invest 1976; 36: 437-445.

3. Kramps JA, Franken C. Low molecular weight protease inhibitor of the respiratory tract. Surv Immunol Res 1982; 1: 30-36.

4. Schiessler H, Hochstrasser K, Ohlsson K. Acid stable inhibitors of granulocyte neutral proteases in human mucus secretions: biochemistry and possible biological function. In: Havemann K, Janoff A, eds. Neutral Proteases of Human Polymorphonuclear Leukocytes. Baltimore-Munich Urban \& Schwarzenberg Inc., 1978; pp. 195-207.

5. Morrison HM, Welgus HG, Stockley RA, Burnett D, Campbell EJ. Inhibition of human leucocyte elastase bound to elastin: relative ineffectiveness and two mechanisms of inhibitory activity. Am J Respir Cell Mol Biol 1990; 2: 263-269. 
6. Bruch M, Bieth JG. Influence of elastin on the inhibition of leucocyte elastase by alpha ${ }_{1}$-proteinase inhibitor and bronchial inhibitor: potent inhibition of elastinbound elastase by bronchial inhibitor. Biochem J 1986; 238: 269-273.

7. Lee CH, Igarashi Y, Hohman RJ, Kaulbach H, White M, Kaliner MA. Distribution of secretory leukoprotease inhibitor in the human nasal airway. Am Rev Respir Dis 1993; 147: 710-716.

8. Puchelle E, Hinnrasky J, Tournier JM, Adnet JJ. Ultrastructural localization of bronchial inhibitor in human airways using protein A-gold technique. Biol Cell 1985; 55: 151-154.

9. de Water R, Willems LNA, van Muijen GNP, et al. Ultrastructural localization of bronchial antileukoprotease in central and peripheral airways by gold-labeling technique using monoclonal antibodies. Am Rev Respir Dis 1986; 133: 882-890.

10. Willems LNA, Kramps JA, Stijnen T, Sterk PJ, Weening JJ, Dijkman JH. Antileukoprotease-containing cells: relationship with morphologic disease of small airways and parenchyma. Am Rev Respir Dis 1989; 139: 1244-1250.

11. Kida K, Mizuuchi T, Asano A, Koyama T, Wada H, Izawa Y. A quantitative study of SLPI-laden cells in the airways of elderly lung. Am Rev Respir Dis 1993; 147(4): A678.

12. Tournier JM, Jacquot J, Sadoul P, Bieth JG, Noncompetitive enzyme immunoassay for the measurement of bronchial inhibitor in biological fluids. Anal Biochem 1983; 131: 345-350.

13. Heinzel R. Appelhans H, Gassen G, et al. Molecular cloning and expression of cDNA for human antileukoprotease from cervix uterus. Eur J Biochem 1986; 160: 6167.

14. Spilmont C, Hinnrasky J, Tournier JM, Chapelier A, Jacquot J, Puchelle E. Differential expression of antileucoprotease by human tracheal gland cells in monolayer and three-dimensional collagen gel cultures (Abstract). Am Rev Respir Dis 1993; 147(4): A50.

15. Lebonvallet S, Mennesson T, Bonnet N, et al. Semiautomatic quantitation of dense markers in cytochemistry. Histochemistry 1991; 96: 245-250.

16. Leube RE, Rustad TJ. Squamous cell metaplasia in the human lung: molecular characteristics of epithelial stratification. Virchows Arch (Cell Pathol) 1991; 61: 227-253.

17. Auerbach O, Gere JB, Forman JB. et al. Changes in the bronchial epithelium in relation to smoking and cancer of the lung. N Engl J Med 1957; 256(3): 97-104.
18. Wang NS, Ying WL. The pattern of goblet cell hyperplasia in human airways. Hum Pathol 1977; 8(3): 301311.

19. Willems LNA, Kramps JA, de Water R, et al. Evaluation of antileukoprotease in surgical lung specimens. Eur $J$ Respir Dis 1986; 69: 242-247.

20. Jeffery PK, Gaillard D, Moret S. Human airway secretory cells during development and in mature airway epithelium. Eur Respir J 1992; 5: 93-104.

21. Tos M, Mogensen C. Mucous glands in nasal polyps. Arch Otolaryngol 1977; 103: 407-413.

22. Tos M. Development of the mucous glands in the human main bronchus. Anatomischer Anzeiger 1968; 123 : 376-389.

23. Jeffery PK, Reid L. The ultrastructural of the airway lining and its development. In: Hodson WA, ed. The Development of the Lung. New York, Dekker, 1977; pp. 87-134.

24. Willems LNA, Kramps JA, Jeffery PK, Dijkman JH. Antileukoprotease in the developing fetal lung. Thorax 1988; 43: 784-786.

25. Benali R, Chevillard M, Zahm JM, Hinnrasky J, Klossek JM, Puchelle E. Tubule formation and functional differentiation by human epithelial respiratory cells cultured in a three-dimensional collagen matrix. Chest 1992; 101: 7S-9S.

26. Niimi T, Imaizumi $M$, Abe $T$, Haimoto $H$, Nagura $H$. Immunohistochemical characteristics of proliferative and metaplastic lesions in bronchial mucosa. Am J Clin Pathol 1987; 88: 545-551.

27. Rogers AV, Dewar A, Corrin B, Jeffery PK. Identification of serous-like cells in the surface epithelium of human bronchioles. Eur Respir J 1993; 6: 498-504.

28. Alkemade HAC, Molhuizen HOF, van Vlijmen-Willems IMJJ, van Haelst UJGM, Schalkwijk J. Differential expression of SKALP/elafin in human epidermal tumors. Am J Pathol 1993; 143: 1679-1687.

29. Norlander T, Fukami M, Westrin KM, Stierna P, Carlsöö B. Formation of mucosal polyps in the nasal and maxillary sinus cavities by infection. Otolaryngol Head Neck Surg 1993; 109: 522-529.

30. Abbinante-Nissen JM, Simpson LG, Leikauf GD. Neutrophil elastase increases secretory leukocyte protease inhibitor transcripts levels in airway epithelial cells. $A m J$ Physiol (Lung Cell Mol Physiol 9) 1993; 265: L286L292.

31. Maruyama M, Hay JG, Yoshimura K, Chu CS, Crystal RG. Modulation of secretory leucoprotease inhibitor gene expression in human bronchial epithelial cells by phorbol ester. J. Clin Invest 1994; 94: 368-375. 